\title{
A case of recurrent pneumonia and lung abscess in an immunocompetent patient
}

\author{
A K M Nizam Uddin, ${ }^{1}$ Peter McLaughlin, ${ }^{1}$ Darren Mansfield, ${ }^{1}$ Kenneth Lau ${ }^{2,3}$
}

${ }^{1}$ Monash Lung \& Sleep, Monash Medical Centre, Clayton, Victoria, Australia ${ }^{2}$ Department of Diagnostic Imaging, Southern Health, Melbourne, Victoria, Australia ${ }^{3}$ Faculty of Medicine, Nursing and Health Sciences, Monash University, Melbourne, Victoria, Australia

\section{Correspondence to} Dr A K M Nizam Uddin, akmnizam@hotmail.com

Accepted 9 January 2015
CrossMark

To cite: Uddin AKMN, McLaughlin P, Mansfield D, et al. BMJ Case Rep Published online: [please include Day Month Year] doi:10.1136/bcr-2014206718

\section{DESCRIPTION}

A 40-year-old man with a history of childhood asthma and recurrent pneumonia was admitted to hospital with fever, shortness of breath and mild productive cough. A chest X-ray showed cavitating right middle lobe opacity (figure 1 ). Subsequent CT scan with three-dimensional reformats confirmed an irregular thick-walled air containing lesion in the right middle lobe in keeping with a pulmonary abscess. In addition, a high density foreign body that measured $2.6 \mathrm{~cm}$ in length was seen within the

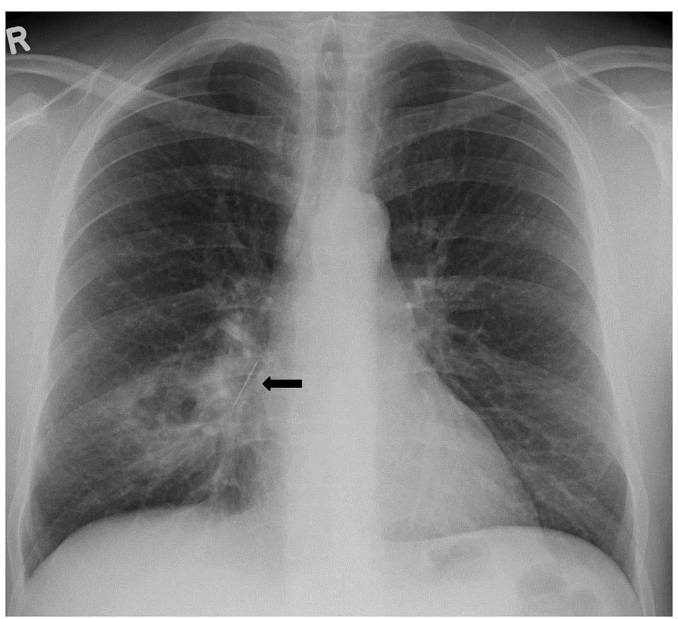

Figure 1 Chest X-ray (posterioranterior view) of the 40-year-old man demonstrated a right middle lobe cavitating opacity and a linear metallic object (arrow) at the inferior aspect of the right hilum. right middle lobe bronchus (figure 2). The proximal end of the linear foreign body was covered by irregular soft tissue densities (figure 3).

A rigid bronchoscopy was undertaken, which revealed a dress pin in the right middle bronchus. Polypoid appearing soft tissues were seen in the distal bronchus intermedius, covering the proximal end of the dressing pin and partially obstructing the right bronchus intermedius and right middle lobe bronchus. Partial occlusion of the airway caused a secondary bacterial pneumonia with cavitation. The pin was removed.

Follow-up flexible bronchoscopy 2 months later showed no progression of the polypoid soft tissue at the distal bronchus intermedius (figure 4). Endobronchial biopsy of this lesion revealed no acute inflammation, granulomatous formation or malignancy. This would be in keeping with fibrous tissue. Subsequent chest X-ray revealed complete resolution of lung abscess (figure 5). The patient was followed up in clinic over the next 12 months and appeared to make a full and uneventful recovery with no asthma symptoms.

Further clinical history revealed that the patient's mother was a dress maker. The patient and his family could not recall any foreign body inhalation. It is likely he inhaled the dress pin as a child, resulting in recurrent pneumonia and, eventually, pulmonary abscess formation due to the significant amount of fibrous tissue that had developed around it. Previous literature review reveals a syndrome known as Turban pin aspiration syndrome, but no relevant history reveals actual cases of it. ${ }^{1}$
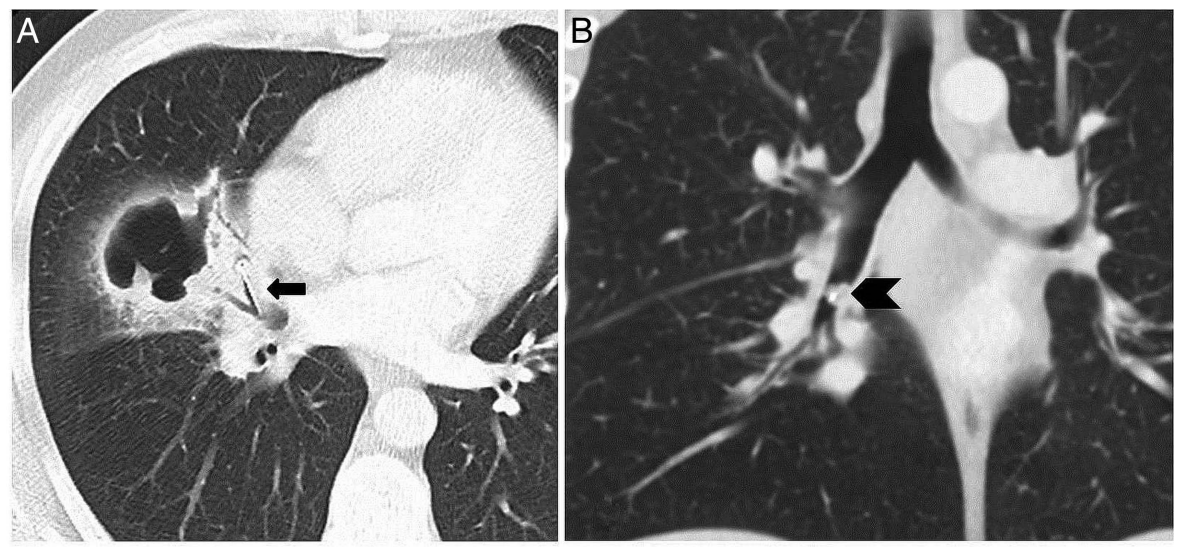

Figure 2 CT of the chest in axial (A) and coronal (B) reformats confirmed the presence of cavitating pulmonary abscess (white arrow) with a linear metallic foreign body impacted at the right middle lobe bronchus (black arrow). There was a soft tissue density (black arrow head) encasing the proximal end of the object. 


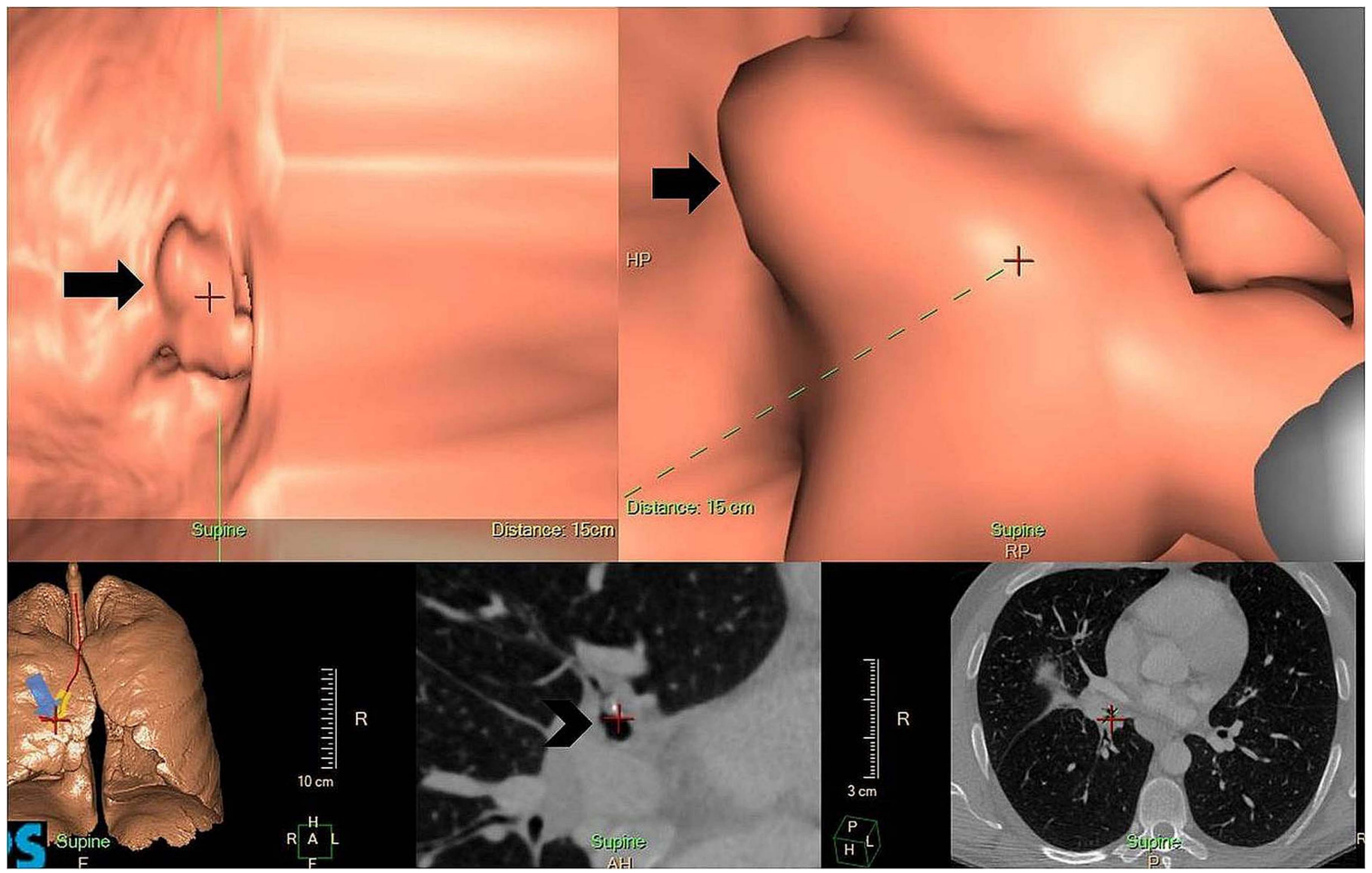

Figure $3 \mathrm{CT}$ of the chest in three-dimensional reformat using surface rendering technique displayed the soft tissue cuff completely covering the proximal end of the metallic foreign body (arrow), which was confirmed on the axial image (arrow head).

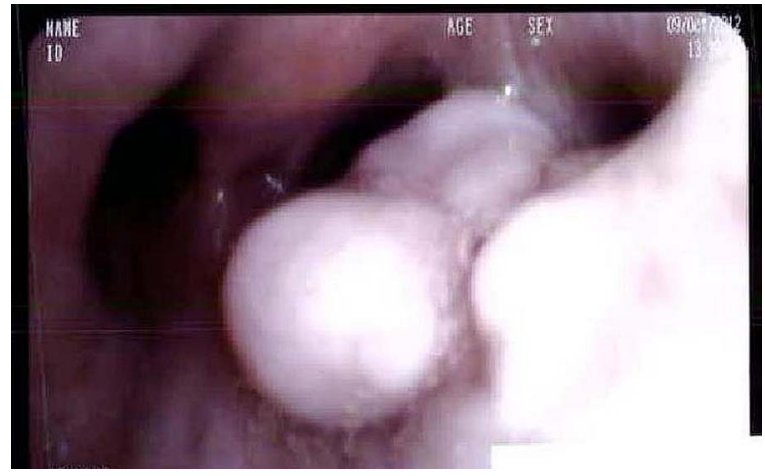

Figure 4 Endobronchial demonstration of polypoid lesion to distal bronchus intermedius.

\section{Learning points}

- Unsuspecting foreign body inhalation would need to be considered as a diagnostic possibility when there has been unexplained recurrent pneumonia.

- Fibrous tissues can develop around a chronically inhaled foreign body over time and cause obstruction to the bronchial lumen.

- CT-chest with three-dimensional reformat is a non-invasive imaging method that has potential for proper localisation of the foreign body in the airway.

Acknowledgements The authors thank to Monash Lung \& Sleep and Monash Radiology Department for their support.

Contributors PML and AKMNU performed the bronchoscopy and were the corresponding physicians for the patient, and DM was the respiratory physician. $\mathrm{KL}$

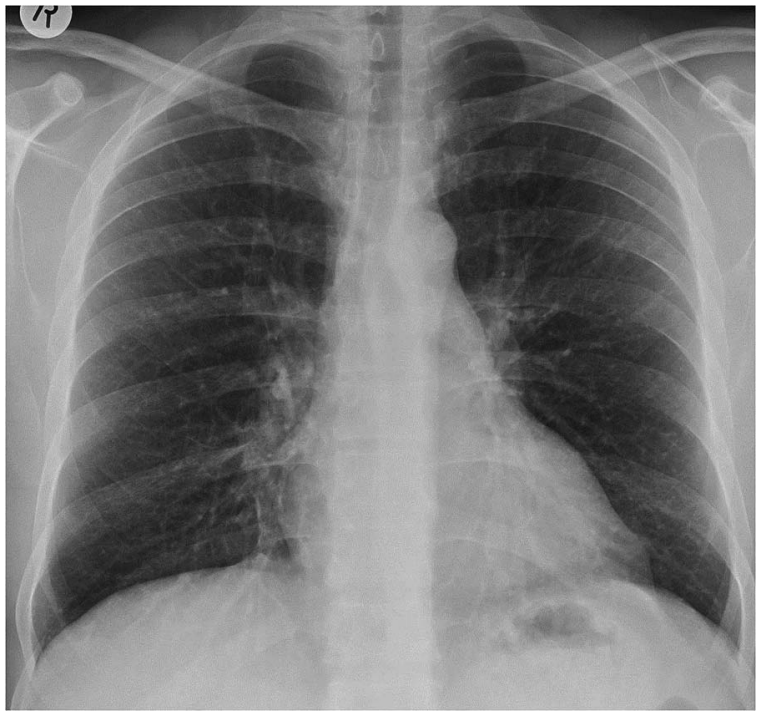

Figure 5 Chest X-ray of the same patient 4 weeks postendoscopic removal of right middle lobe bronchus foreign body showed complete resolution of right lung pulmonary abscess and no sign of any residual foreign body.

was our senior radiologist and provided his valuable input from the radiological point of view.

Competing interests None.

Patient consent Obtained.

Provenance and peer review Not commissioned; externally peer reviewed.

\section{REFERENCE}

1 Ilan 0 , Eliashar R, Hirshoren $N$, et al. Turban pin aspiration: new fashion, new syndrome. Laryngoscope 2012;122:916-19. 
Copyright 2015 BMJ Publishing Group. All rights reserved. For permission to reuse any of this content visit http://group.bmj.com/group/rights-licensing/permissions.

BMJ Case Report Fellows may re-use this article for personal use and teaching without any further permission.

Become a Fellow of BMJ Case Reports today and you can:

- Submit as many cases as you like

- Enjoy fast sympathetic peer review and rapid publication of accepted articles

- Access all the published articles

- Re-use any of the published material for personal use and teaching without further permission

For information on Institutional Fellowships contact consortiasales@bmjgroup.com

Visit casereports.bmj.com for more articles like this and to become a Fellow 